MSC 76Q05

DOI: $10.14529 / \mathrm{mmp200102}$

\title{
ACOUSTIC WAVES PROPAGATION IN HEATED WATER WITH VAPOR BUBBLES
}

\author{
U.O. Agisheva ${ }^{1}$, M.N. Galimzyanov ${ }^{1}$ \\ ${ }^{1}$ Mavlyutov Institute of Mechanics UFRC RAS, Ufa, Russian Federation \\ E-mails: agisheva_u@mail.ru, monk@anrb.ru
}

\begin{abstract}
The problems of wave propagation in bubbly media are of great interest for researchers for nearly half a century due to the wide distribution of these systems in nature and their intense use in modern technology. It is known that the attenuation intensity of sound disturbances in the gas-liquid media is mainly determined by the thermophysical characteristics of the gas in bubbles. It turns out that these effects are significantly observable with increasing of steam concentration due to system temperature get higher. In this paper, we consider the propagation of small perturbations in a liquid with bubbles filled with vapor and gas insoluble in the liquid phase in an one-dimensional and one-velocity approximation. In order to take into account interfacial heat and mass transfer, we use the heat and diffusion equations inside the bubble and the heat equation in the fluid around the bubble. A dispersion equation was written from the existence condition of the solution in the form of a damped traveling wave, taking into account the effects of acoustic unloading of bubbles, and numerical calculations were carried out for water with vapor-gas bubbles. We investigate the features of the reflection of harmonic waves from the interface of "pure" liquid and liquid with vapor-gas bubbles. Also, we carry out a numerical analysis of the effect of the initial volume gas content $\alpha_{g 0}$ with two initial bubble sizes $a_{0}=10^{-6} \mathrm{~m}$ and $10^{-3} \mathrm{~m}$. Finally, we study the effect of disturbance frequencies and temperature of the media on the attenuation coefficient of sound.
\end{abstract}

Keywords: water-air bubble medium; bubbles; phase transition; harmonic waves; phase velocity; damping factor.

\section{Introduction}

It is known that a bubble liquid is a system with unique wave properties [1,2]. Problems of the wave propagation in such media have been of great interest to researchers for almost half a century due to the wide spread of this systems in nature and their intensive use in modern technology.

The papers [3-6] consider a stationary flow of a bubble gas-liquid mixture in a nozzle of circular cross-section and analyze the possibility of realizing of superhigh temperatures and pressures in the gas phase at the nozzle section near the minimum cross section. Also, the papers study the effect of the parameters (the initial radius and the volume content of bubbles determining the composition of the volume flow of liquid fed into the nozzle) on the flow pattern.

The papers [7-10] present the developed models of a gas-liquid mixture for investigating low-amplitude pressure waves in bubble media. The case of strong shock waves is considered in [11-13]. In the two-dimensional formulation for low-intensity pressure waves, the criteria for quenching and amplifying the wave signal in bubble regions of finite dimensions $[7,9,10]$ are determined. It is established that in the evolution of a pulsed signal in a homogeneous bubble liquid, a leading wave and a divergent 
wave packet [8] can form in the transverse coordinate of the pulse signal. For a reliable description of the thermodynamic properties of bubble liquids under conditions of strong shock waves, a wide-range equation of state of water and vapor was used in analytical form. Calculations were compared with the experiments for hydrocarbons with a pressure amplitude $p_{1}=2,4 \mathrm{MPa}$ in water with nitrogen bubbles with an initial gas content of $\alpha_{20}=4$. The processes of propagation and reflection of the shock wave from the rigid wall were analyzed with a change from $\alpha_{20}=0,5$ to $6 \%$ and the amplitude of the shock wave from 2 to $100 \mathrm{MPa}$ [9-12]. The pressure range from $100 \mathrm{MPa}$ to $100 \mathrm{GPa}$ was considered in [13].

The paper [14] investigates the features of the dynamics of two-dimensional pressure waves of weak intensity in a layered bubble liquid. The effect of the initial bubble radius on the wave propagation is analyzed. The possibility of formation of pressure peaks near the boundary between layers is studied.

The work [15] considers reflection and refraction of acoustic waves at the interface between air and fog. The phase velocity and the sound attenuation coefficient for the fog, as well as the reflection and refraction coefficients for the normal and oblique incidence of the wave are calculated. The dependence of the refraction angle on the frequency and the angle of incidence of the acoustic wave on the interface between air and fog is studied. On the basis of the obtained analytical expressions and analysis of numerical calculations, it is established that in the case when the wave falls from the side of the fog to the interface, there is a critical angle of incidence such that, complete internal reflection occurs at full angles. It is shown that total internal reflection does not occur when the wave falls from the air side to the boundary between air and fog.

The paper [16] studies the reflection and refraction of acoustic waves at different angles of incidence on the interface between a vapor-gas-droplet system and air. From an analysis of analytical solutions, it was found that in the case of incidence on the interface from the side of the vapor-gas-droplet medium, there is a critical angle of incidence at which the wave is completely reflected from the boundary, i.e. total internal reflection takes place. It is shown that for a certain angle of incidence on the interface both from the air side and from the mixture side and for a certain volume fraction of water in the disperse system, complete transmission of the acoustic wave through the medium is observed.

In [17], the features of reflection and refraction of acoustic waves at the interface between pure water and bubbly water are investigated for the case of oblique incidence. From an analysis of analytic solutions, it follows that, for a wave incident on the interface from the side of a bubbly liquid, there exists a critical angle of incidence, which depends on the frequency and the parameters of the disperse system, that the wave is totally reflected from the interface at angles of incidence exceeding the critical one.

The works $[18,19]$ present the results of studies on the acoustic effects on multifractional mixtures of liquid with vapor-gas and gas bubbles of various sizes and different compositions with phase transformations.

The paper [20] numerically analyzes the influence of variations of equilibrium initial temperature of a system in the range from 300 to 373 for two initial bubble sizes $a_{0}=10^{-6}$ and $10^{-3} \mathrm{~m}$. The effect of the perturbation frequencies on the reflection coefficient and refraction index at normal incidence was studied. It was shown that the condition of total internal reflection can be fulfilled by the incidence of a wave from a bubbly liquid at the interface.

Вестник ЮУрГУ. Серия «Математическое моделирование

и программирование» (Вестник ЮУрГУ ММП). 2020. Т. 13, № 1. С. 28-38 
The work [21] studies the characteristics of the reflection and refraction of harmonic waves at its "oblique" incidence on an interface between a "pure" liquid and liquid with bubbles filled with a vapor-gas mixture. For the considered problem, we obtained the dispersion equation and carried out a numerical analysis of the effect of the perturbation frequencies in the range $10^{2}-10^{7} \mathrm{~s}^{-1}$ on the dependence of the angle of refraction on that of incidence for three equilibrium initial temperatures. Also for the same reflection, we studied The dependence of the critical angle of incidence on the parameters of a two-phase system and the perturbation frequencies.

In $[22,23]$, maps of the stability regions of the investigated systems are constructed as functions of the degree of overheating of the liquid. The influence of the initial degree of overheating (from hundredths to one degree) and pressure increase on the evolution of harmonic waves is analyzed. For unstable systems, the dependence of the increment on bubble radius with increasing degree of water overheating is studied.

Analysis of the previous works shows that the intensity of attenuation of sound disturbances in the considered systems is mainly determined by the thermophysical characteristics of the gas in the bubbles. It turns out that these effects are greatly enhanced with an increase in the vapor concentration due to an increase in the temperature of the system.

\section{Governing Equations}

Suppose that a liquid with the temperature $T_{0}$ and pressure $p_{0}$ contains spherical bubbles with the radius $a_{0}$ filled with vapor and gas insoluble in the liquid phase. Let us consider the propagation of small perturbations in the described system in a planar one-dimensional and one-velocity approximation. Assuming that the liquid is acoustically compressible, we can write the following linearized equation for the pressure $p_{l}$, velocity, and bubble radius oscillations [2]:

$$
\frac{1-\alpha_{g 0}}{C_{l}^{0}} \frac{\partial p_{l}}{\partial t}+\rho_{l 0}^{0} \frac{\partial v}{\partial x}-3 \rho_{l 0}^{0} \frac{\alpha_{g 0}}{a_{0}} \frac{\partial a}{\partial t}=0,
$$

where $v$ is the velocity of the medium, $a$ is the radius of the bubbles, and $C_{l}^{0}$ is the frozen speed of sound in the liquid, $\alpha_{g 0}$ is the volume content of the void fraction, $\rho_{l 0}^{0}$ is the dencity of phases in initial undisturbed state.

The momentum equation has the form

$$
\rho_{l 0}^{0}\left(1-\alpha_{g 0}\right) \frac{\partial v}{\partial t}+\frac{\partial p_{l}}{\partial x}=0
$$

We assume that the perturbations of the pressure in the liquid $p_{l}$ and in the bubbles $p_{g}=p_{v}+p_{a}$ are connected by the Rayleigh-Lamb equation. After linearization, we take into account the capillary forces, and rewrite the Rayleigh-Lamb equation as follows:

$$
\rho_{l 0}^{0} a_{0} \frac{\partial^{2} a}{\partial t^{2}}+4 \frac{\rho_{l 0}^{0} \nu_{l}^{(\mu)}}{a_{0}} \frac{\partial a}{\partial t}=p_{g}-p_{l}+\frac{2 \sigma}{a_{0}^{2}} a .
$$

Here $\nu_{l}^{(\mu)}$ is the kinematic viscosity of the liquid.

We write the equation of heat conduction and diffusion inside the bubble as well as the heat equation in the liquid around the bubble to take into account the interfacial heat and mass transfer as follows:

$$
\rho_{g 0}^{0} c_{g} \frac{\partial T_{g}^{\prime}}{\partial t}=\frac{\lambda_{g}}{r^{2}} \frac{\partial}{\partial r}\left(\lambda_{g} r^{2} \frac{\partial T_{g}}{\partial r}\right)+\frac{\partial p_{g}}{\partial t}, \quad \frac{\partial k^{\prime}}{\partial t}=\frac{D}{r^{2}} \frac{\partial}{\partial r} r^{2} \frac{\partial k^{\prime}}{\partial r} \quad\left(0<r<a_{0}\right),
$$




$$
\rho_{l 0}^{0} c_{l} \frac{\partial T_{l}^{\prime}}{\partial t}=\frac{\lambda_{l}}{r^{2}} \frac{\partial}{\partial r}\left(r^{2} \frac{\partial T_{l}^{\prime}}{\partial r}\right) \quad\left(a_{0}<r<a_{0} \alpha_{g 0}^{-1 / 3}\right) .
$$

The prime mark indicates that, in addition to $x$ and $t$ these parameters depend on the radial coordinate $r$ counted from the center of a bubble. Here $k$ is mass concentration of vapor phase, $T_{g}, T_{l}, c_{g}, c_{l}, \lambda_{g}, \lambda_{l}$ denote the temperature, specific heat and thermal conductivity of the gas and liquid phases respectively, $D$ is a coefficient of diffusion.

On the interface of phases $\left(r=a_{0}\right)$, we define the boundary conditions following from the conditions for the balance of heat and mass as follows:

$$
T_{g}^{\prime}=T_{l}^{\prime}=T_{(a)}, \quad k^{\prime}=k_{(a)}, \quad \lambda_{l} \frac{\partial T_{l}}{\partial r}-\lambda_{g} \frac{\partial T_{g}}{\partial r}=j l, \quad j=\frac{D}{1-k_{0}}\left(\frac{\partial k^{\prime}}{\partial r}\right)_{r=a_{0}},
$$

where $l$ is specific heat of water vapor formation, $j$ is a mass transfer intensity, $T_{(a)}$ and $k_{(a)}$ are perturbations of temperature and vapor concentration on the bubble surface, respectively.

For the gas pressure inside the bubble, we have:

$$
\begin{gathered}
\frac{\partial p_{g}}{\partial t}=-3 \gamma \frac{p_{g 0}}{a_{0}} \frac{\partial a}{\partial t}+3(\gamma-1) \frac{\lambda_{g}}{a_{0}}\left(\frac{\partial T_{g}^{\prime}}{\partial r}\right)_{r=a_{0}}+3 \frac{\gamma p_{g 0}}{a_{0}} \frac{B_{v}}{\left(1-k_{0}\right) B_{g 0}}\left(\frac{\partial k^{\prime}}{\partial r}\right)_{r=a_{0}}, \\
\gamma=c_{g 0} /\left(c_{g 0}-B_{0}\right), \quad c_{g 0}=c_{v} k_{0}-c_{a}\left(1-k_{0}\right) .
\end{gathered}
$$

For the initial undisturbed state, we write the following equation:

$$
\frac{p_{s}\left(T_{0}\right)}{p_{g 0}}=\frac{B_{v} k_{0}}{B_{a}+\left(B_{v}-B_{a}\right) k_{0}},
$$

which uniquely relates to the mass concentration of vapor in the bubble with temperature $T_{0}$. In order to determine $p_{s}(T)$, we use the formula $p_{s}(T)=p_{*} \exp \left(-T_{*} / T\right)$, where $p_{*}, T_{*}$ are the empirical parameters depended on the type of liquid.

\section{Dispersive Analysis}

Let us find the solution of the above system in the form of a damped traveling wave:

$$
\begin{gathered}
p_{l}, \quad p_{g}, \quad v, \quad a \sim \exp [i(K x-\omega t)], \quad T_{i}^{\prime}=T_{i}(r) \exp [i(K x-\omega t)], \quad(i=g, l), \\
k^{\prime}=k(r) \exp [i(K x-\omega t)], \quad K=k+i \delta, \quad C_{p}=\omega / k, \quad i=\sqrt{-1},
\end{gathered}
$$

where $K$ is the wave vector, $\delta$ and $C_{p}$ are the damping coefficient and the phase velocity of the wave, respectively. From the condition for the existence of a solution of this type, taking into account the acoustic discharge effects [24] of bubbles, we obtain the dispersion equation

$$
\begin{gathered}
\frac{K^{2}}{\omega^{2}}=\frac{\left(1-\alpha_{g 0}\right)^{2}}{C_{l}^{2}}+3 \frac{\rho_{l 0}^{0} \alpha_{g 0}\left(1-\alpha_{g 0}\right)}{\psi} \\
\psi=\frac{3 \gamma p_{g 0}}{Q}-\frac{\rho_{l 0}^{0} \omega^{2} a_{0}^{2}}{\xi}-4 i \rho_{l 0}^{0} \nu_{\ell}^{(\mu)} \omega-\frac{2 \sigma}{a_{0}} \\
p_{g 0}=p_{0}+\frac{2 \sigma}{a_{0}}, \quad \xi=1-i \omega t_{A}, \quad t_{A}=\frac{a_{0}}{\sqrt[3]{\alpha_{v 0}} C_{l}}, \\
Q=1+\left(\frac{\gamma-1}{k_{0}} H_{a} k h\left(y_{g}\right)+\frac{\gamma}{1-k_{0}} H_{v} k h(z)\right)\left(\frac{H_{a}}{k_{0}}+\frac{\gamma k h(z)}{\left(1-k_{0}\right) \beta \sinh v\left(y_{l}\right)}\right)^{-1} \\
k h(x)=3(x \operatorname{coth} x-1) x^{-2}
\end{gathered}
$$




$$
\begin{gathered}
\sinh v(x)=3\left(1+x \frac{\left(A_{0} x \tanh x\left(A_{0}-1\right)-1\right)}{\left(A_{0} x-\tanh x\left(A_{0}-1\right)\right)^{-1}}\right) x^{-2} \text { or } \sinh v(x)=3(1+x) x^{-2}, \\
A_{0}=\alpha_{g 0}^{-1 / 3}, \quad y_{l}=\sqrt{-i \omega a_{0}^{2} / \nu_{l}^{(T)}}, \quad z=\sqrt{-i \omega a_{0}^{2} / D}, \quad \beta=(\gamma-1) \eta H_{v} \chi^{2}, \\
\eta=\frac{\rho_{l 0}^{0} c_{1}}{\rho_{g 0}^{0} c_{g}}, \quad \chi=\frac{c_{g} T_{0}}{l}, \quad H_{v}=\frac{B_{v}}{B_{0}}, \quad H_{a}=\frac{B_{a}}{B_{0}}, \quad H=H_{v}-H_{a} .
\end{gathered}
$$

For $\omega \rightarrow 0$, dispersion equation (8) involve the following formula for the equilibrium velocity of sound:

$$
C_{e}=\sqrt{\frac{p_{g 0}}{\rho_{l 0}^{0} \alpha_{g 0}}\left(\left(1-k_{0}\right) H_{a}+k_{0} \frac{\alpha_{g 0} \gamma}{\beta}\right)-\frac{2}{3} \frac{\sigma}{a_{0} \rho_{l 0}^{0} \alpha_{g 0}}},
$$

which generalizes the well-known Malloch and Landau formulas [25]. In particular, at the boiling point $T_{0}=T_{s}\left(p_{0}\right)$, taking into account the expressions from the dispersion equation, we obtain

$$
C_{e}=\sqrt{k_{0}\left(\frac{\rho_{g 0}^{0}}{\rho_{l 0}^{0}}\right)^{2}\left(\frac{B_{0}}{B_{v}}\right)^{2} \frac{l^{2}}{C_{l} T_{0}}+\frac{4}{3} \frac{\sigma}{a_{0} \rho_{l 0}^{0} \alpha_{g 0}}} .
$$

\section{Numerical Results}

Numerical calculations for water with vapor-gas bubbles were carried out on the basis of above-mentioned dispersion equation. The data from [26] were used as the values of the physical and thermophysical parameters. All calculations were carried out for a liquid under pressure $p_{0}=0,1 \mathrm{MPa}$.

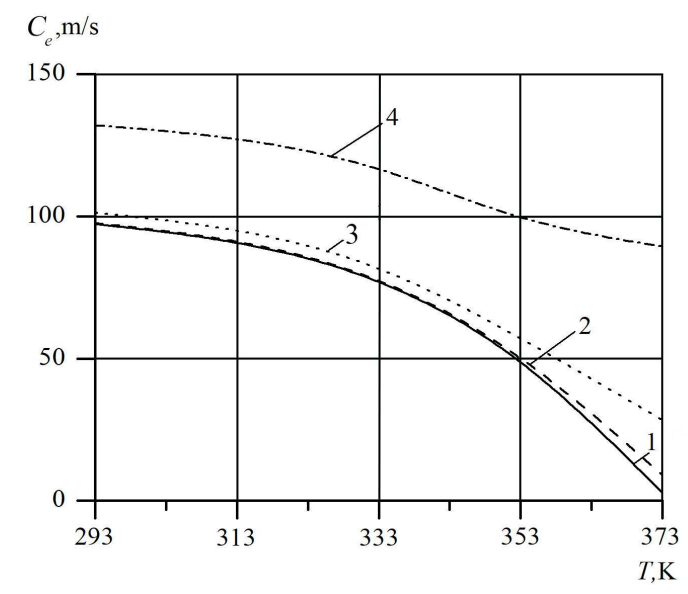

Fig. 1. Dependence of the equilibrium speed of sound on temperature for $\alpha_{g 0}=$ $10^{-2}$

Figs. 1 and 2 show the dependence of the equilibrium velocity of sound determined by equation (11) on the water temperature $T_{0}$ for $\alpha_{g 0}=10^{-2}$ (Fig. 1) and $\alpha_{g 0}=10^{-3}$ (Fig. 2) under the condition $\omega \leq \omega_{l}^{(T)}\left(\omega_{l}^{(T)}=\nu_{l}^{(T)} /\left(a_{0} / \alpha_{g 0}^{2 / 3}\right)\right.$. Lines $1,2,3$, and 4 correspond to the values $a_{0}=10^{-3}, 10^{-4}, 10^{-5}$ and $10^{-6} \mathrm{~m}$. It is easy to see that the magnitude of the equilibrium velocity increases as the radius of the bubbles decreases. This is due to the 
increase in the "rigidity" of the bubbles depending on the capillary forces on the interphase surface and the phase transitions.

Fig. 3 represents the dependence of the phase velocity (a) and the damping coefficient (b) on the perturbation frequency for different values of the equilibrium temperature $T_{0}$ and initial void fraction volume $\alpha_{g 0}=10^{-2}$. The dashed line indicates the case of a coarse bubble media $\left(a_{0}=10^{-3} \mathrm{~m}\right)$, while the dotted line corresponds to a highly dispersed media $\left(a_{0}=10^{-6} \mathrm{~m}\right)$. Solid lines 1,2 and 3 correspond to the values of equilibrium temperature $T_{0}=300,353$ and $373 \mathrm{~K}$. The diagrams show that with increase in the equilibrium temperature the phase velocity decreases approximately $2-3$ times in the lowfrequency zone ( $\omega \ll \omega_{R}$, where $\omega_{R}$ is the Minnaert resonance of the bubbles). According to the calculation results presented in (b), a sudden change of the damping coefficient $\delta$ is observed. In particular, for the frequency value $\omega=10^{3} \mathrm{~s}^{-1}$, the value of the damping coefficient $\delta$ increases from $10^{-1} \mathrm{~m}^{-1}$ to $5 \mathrm{~m}^{-1}$, and for the frequency value $\omega=10^{4} \mathrm{~s}^{-1}$ the value $\delta$ increases from $1 \mathrm{~m}^{-1}$ to $10 \mathrm{~m}^{-1}$. Analyzing the results obtained, we can conclude that, in the low-frequency zone, an increase in temperature from normal conditions to the boiling liquid improve weak perturbations damping by more than an order (tens of times).
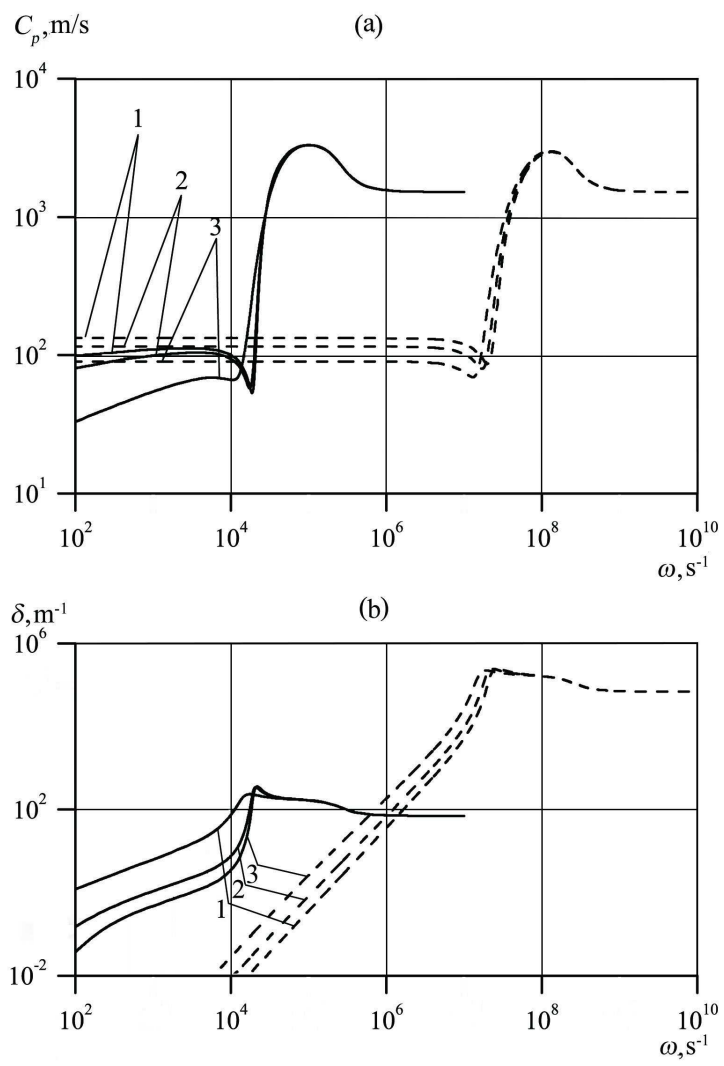

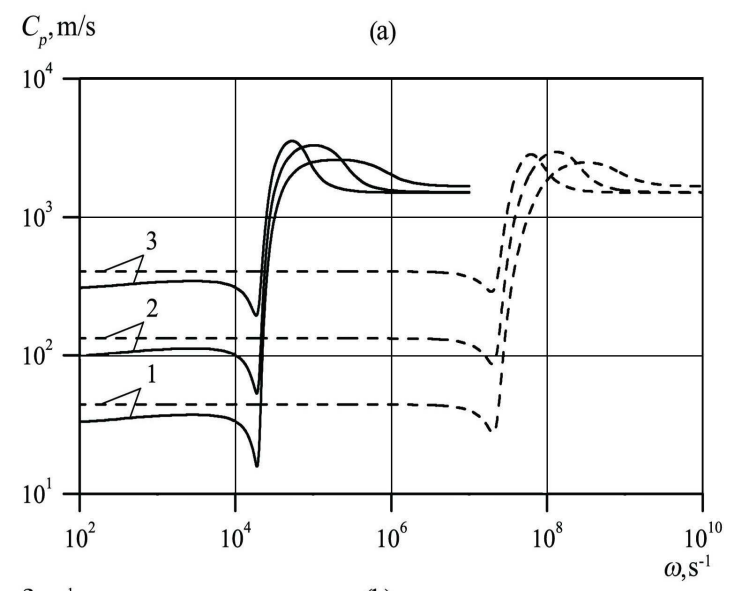

$\delta, \mathrm{m}^{-1}$

(b)

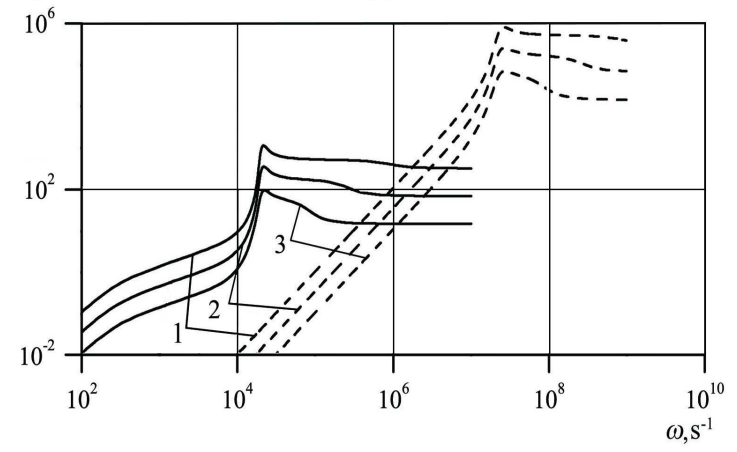

Fig. 3. The dependence of the phase velocity (a) and the damping coefficient (b) on the frequency of the perturbations. $1-T_{0}=300 \mathrm{~K}, 2-T_{0}=353 \mathrm{~K}, 3-$ $T_{0}=373 \mathrm{~K}$
Fig. 4. The dependence of the phase velocity (a) and the damping coefficient (b) on the frequency of the perturbations. $1-\alpha_{g 0}=10^{-1}, 2-\alpha_{g 0}=10^{-2}, 3-$ $\alpha_{g 0}=10^{-3}$ 
Fig. 4 shows the dependence of the phase velocity (a) and the damping coefficient (b) on the frequency of the perturbations for different values of the initial void fraction volume $\alpha_{g 0}$ at the equilibrium temperature $T_{0}=373 \mathrm{~K}$. The dashed line indicates the case of a coarse media $\left(a_{0}=10^{-3} \mathrm{~m}\right)$, while the dotted line corresponds to a highly dispersed media $\left(a_{0}=10^{-6} \mathrm{~m}\right)$. Solid lines 1,2 and 3 correspond to the values of volumetric contents $\alpha_{g 0}=10^{-1}, 10^{-2}$ and $10^{-3}$. The diagrams show that with a decrease in the volumetric content the phase velocity increases approximately 5 times in the low-frequency region $\left(\omega \ll \omega_{R}\right)$. Note that, in the low-frequency region a small increase in the phase velocity from the disturbance frequency is also characteristic for a coarse media, while the phase velocity is constant for a highly dispersed media. It takes place because of the role of phase transitions increases in the low frequencies. Due to phase transitions vapor - gas bubbles with a small mass content of an inert gas become less elastic. In the considered case, the elasticity of the bubbles is mainly determined by the mass content of the gas. In the zone where the frequency of the external perturbation is comparable with the Minnaert resonance of the bubbles $\left(\omega \sim \omega_{R}\right)$, a strong increase in the phase velocity occurs. Moreover, the larger the initial volumetric content of bubbles, the greater the change in phase velocity. Similar pictures are observed for the damping coefficient.

\section{Conclusion}

For the cases considered, it is established that as the bubble radius decreases the equilibrium velocity increases. This is due to the increase in the "rigidity" of the bubbles, which depends on the capillary forces on the interphase surface and the phase transitions.

The study of harmonic waves in a liquid with vapor-air bubbles of the fixed sizes shows that the damping coefficient varies insignificantly when the initial gas volumetric content $\alpha_{g 0}$ changes from $10^{-3}$ to $10^{-1}$ at the equilibrium temperature $T_{0}=373 \mathrm{~K}$ near the low frequencies $\left(\omega \leq \omega_{R}\right)$.

Also, it was also found that with a decrease in the volume content the phase velocity increases approximately 10 times in the low-frequency region $\left(\omega \ll \omega_{R}\right)$ and the damping coefficient $\delta$ decreases with decreasing $\alpha_{g 0}$.

Acknowledgment. The work was supported by the state budget for the state task for 2019-2022 years (project 0246-2019-0052).

\section{References}

1. Kutateladze S.S., Nakoryakov V.E. Teplomassoobmen $i$ volni v gazozhidkostnikh sistemakh [Heat and Mass Transfer in Gas-Liquid Systems]. Novosibirsk, Nauka, 1984. (in Russian)

2. Nigmatulin R.I. Dinamika mnogofaznikh sistem. [Dynamics of Multiphase Media]. Moscow, Nauka, 1987. (in Russian)

3. Shagapov V.Sh., Lepikhin S.A., Galimzyanov M.N. Realization of High Pressures and Temperatures in the Gas Phase of a Bubble Liquid Flowing Through a Nozzle. Journal of Engineering Physics and Thermophysics, 2007, vol. 80. no. 6. pp. 1206-1209. DOI: $10.1007 / \mathrm{s} 10891-007-0155-0$

4. Galimzyanov M.N., Lepikhin S.A. [Flow of a Two-Phase Mixture Through a Different Taking Into Account Phase Transitions]. Vestnik of Samara University. Natural Science Series, 2010, vol. 76 , no. 2 , pp. 96-104. (in Russian) 
5. Galimzyanov M.N., Lepikhin S.A., Chiglintsev I.A. [Distribution of Nonlinear Waves in Access Channels Accompanied by the Formation of Gas Hydrate]. Vestnik of Samara University. Natural Science Series, 2012, vol. 94, no. 3/1, pp. 103-115. (in Russian)

6. Bolotnova R.Kh., Galimzianov M.N., Topolnikov A.S., Agisheva U.O., Buzina V.A. The Hydrodynamic Processes in Bubbly Liquid Flowing in Tubes and Nozzles. WASET, 2012, no. 68, pp. 1992-1999.

7. Nigmatulin R.I., Shagapov V.Sh., Gimaltdinov I.K., Galimzyanov M.N. Two-Dimensional Pressure Waves in a Liquid Containing Bubble Zones. Doklady Physics, 2001, vol. 46, no. 6, pp. 445-451. DOI: $10.1134 / 1.1384945$

8. Galimzyanov M.N., Gimaltdinov I.K., Shagapov V.Sh. Two-Dimensional Pressure Waves in a Fluid with Bubbles. Fluid Dynamics, 2002, vol. 37, no. 2, pp. 139-147. DOI: 10.1023/A:1015818602291

9. Galimzyanov M.N. Propagation of Compression Waves in Finite-Size Bubbles Zones. Vestnik Udmurtskogo Universiteta. Matematika. Mekhanika. Komp'yuternye Nauki, 2010, no. 2, pp. 57-66. (in Russian) DOI: 10.20537/vm100205

10. Bolotnova R.Kh., Galimzyanov M.N., Topolnikov A.S., Buzina V.A., Agisheva U.O. Nonlinear Effects in Bubbly Liquid with Shock Waves. WASET, 2012, no. 68, pp. 2000-2007.

11. Bolotnova R.Kh., Galimzianov M.N., Agisheva U.O. [Modelling of the Processes of Interaction of Strong Shock Waves in Gas-Liquid Mixtures]. University Proceedings. Volga Region. Physical and Mathematical Sciences, 2011, no. 2, pp. 3-14. (in Russian)

12. Agisheva U.O., Bolotnova R.K., Buzina V.A., Galimzyanov M.N. Parametric Analysis of the Regimes of Shock-Wave Action on Gas-Liquid Media. Fluid Dynamics, vol. 48, no. 2, pp. 151-162. DOI: 10.1134/S0015462813020038

13. Hawker N.A., Ventikos Y. Interaction of a Strong Shockwave with a Gas Bubble in a Liquid Medium: a Numerical Study. Journal of Fluid Mechanics, 2012, no. 701, pp. 59-97. DOI: $10.1017 / \mathrm{jfm} .2012 .132$

14. Agisheva U.O., Galimzyanov M.N., Zaliaeva E.Z. Propagation of Weak Pressure Waves in a Liquid Containing Bubble Layer. Proceedings of the Mavlyutov Institute of Mechanics, 2017, vol. 12(2), pp. 244-249. DOI: 10.21662/uim2017.2.037

15. Shagapov V.S., Zainullina O.A. Propagation of Small Disturbances in the Aboiling Liquid Containing Gas Nuclei. High Temperature, 2015, vol. 53, no. 1, pp. 91-97. DOI: $10.1134 /$ S0018151X14050162

16. Shagapov V.Sh., Sarapulova V.V. Characteristic Features of Reflection and Rarefaction of Acoustic Waves at the Interface Between a Gas and a Dispersed System. Journal Applied Mechanics and Technical Physics, 2015, vol. 56, no. 5, pp. 119-129. DOI: 10.1134/S0021894415050107

17. Shagapov V.Sh., Sarapulova V.V. Characteristic Features of Rarefaction and Reflection of Sound at the Boundary of a Bubble Liquid. Acoustical Physics, 2015, vol. 61, no. 1, pp. 37-44. DOI: $10.1134 / \mathrm{S} 1063771014060153$

18. Gubaidullin D.A., Fedorov Y.V. Acoustics of a Polydisperse Vapor-Gas Bubbles-Laden Liquid. Journal of Engineering Physics and Thermophysics, 2017, vol. 90, no. 2, pp. 301-309. DOI: 10.1007/s10891-017-1568-z

19. Gubaidullin D.A., Nikiforov A.A. Attenuation of the Acoustic Signal Propagating Through a Bubbly Liquid Layer. Journal of Engineering Physics and Thermophysics, 2018, vol. 91, no. 1, pp. 201-206. DOI: 10.1007/s10891-018-1736-9 
20. Shagapov V.Sh., Galimzyanov M.N., Vdovenko I.I. Characteristics of the Reflection and Refraction of Acoustic Waves at Normal Incidence on the Interface Between "Pure" and Bubbly Liquids. High Temperature, 2019, vol. 57, no. 2, pp. 246-262. DOI: 10.1134/S0018151X1901022X

21. Shagapov V.Sh., Galimzyanov M.N., Vdovenko I.I. Characteristics of the Reflection and Refraction of Acoustic Waves at "Oblique" Incidence on the Interface Between "Pure" and Bubbly Liquids. High Temperature, 2019, vol. 57, no. 3, pp. 425-429. DOI: 10.1134/S0018151X19020184

22. Shagapov V.Sh., Galimzyanov M.N., Vdovenko I.I. Characteristics of the Stability and Acoustic Properties of Superheated Liquid with Gas Nuclei Under Increasing Pressure. High Temperature, 2019, vol. 57, no. 5, pp. 712-717. DOI: 10.1134/S0018151X19050146

23. Shagapov V.Sh., Galimzyanov M.N., Vdovenko I.I. Acoustics and Stability of an Overheated Liquid with Gas Bubbles. Journal of Applied Mechanics and Technical Physics, 2019, vol. 60, no. 3, pp. 473-482. DOI: 10.1134/S002189441903009X

24. Nigmatulin R.I., Shagapov V.Sh., Vakhitova N.K. Manifestation of the Carrying Phase Compressibility During Propagation of a Wave in a Bubble Medium. Doklady Akademii Nauk, 1989, vol. 304, no. 5, pp. 1077-1081.

25. Landau L.D., Lifshitz E.M. Gidrodinamika [Hydrodynamics]. Moscow, Fizmatlit, 2006.

26. Vargaftik N.B. Spravochnik thermophyzicheskihk svoystv gazov i zhidkostei [Handbook on Thermophysical Properties of Gases and Liquids], Moscow, Nauka, 2006.

Received April 4, 2019

УДК $519.816+519.83$

DOI: $10.14529 / \mathrm{mmp200102}$

\title{
РАСПРОСТРАНЕНИЕ АКУСТИЧЕСКИХ ВОЛН В ТЕПЛОЙ ВОДЕ С ПАРОГАЗОВЫМИ ПУЗЫРЫКАМИ
}

\author{
У.О. Агишева ${ }^{1}$, М.Н. Галимзянов ${ }^{1}$
}

${ }^{1}$ Институт механики им. Р.Р. Мавлютова УФИЦ РАН, г. Уфа, Российская Федерация

Проблемы распространения волн в пузырьковых средах представляют большой интерес для исследователей на протяжении почти полувека в связи с широким распространением этих систем в природе и их интенсивным использованием в современных технологиях. Из литературы известно, что интенсивность затухания звуковых возмущений в рассматриваемых газожидкостных средах в основном определяется теплофизическими характеристиками газа, находящегося в пузырьках. Оказывается, что эти эффекты значительно усиливаются с ростом концентрации пара, обусловленного повышением температуры системы. В работе рассмотрено в плоскоодномерном и односкоростном приближении распространение малых возмущений в жидкости с пузырьками, заполненными паром, и не растворимым в жидкой фазе газом. Для учета межфазного тепломассообмена использовались уравнения теплопроводности и диффузии внутри пузырька и уравнение теплопроводности в жидкости вокруг пузырька. Из условия существования решения в виде затухающей бегущей волны с учетом эффектов акустической разгрузки пузырьков выписано дисперсионное уравнение, проведены численные расчеты для воды с парогазовыми пузырьками. Исследованы особенности отражения гармонических волн от границы раздела «чистой» жидкости и жидкости с парогазовыми пузырьками. Проведен численный анализ влияния начального объем- 
ного газосодержания $\alpha_{g 0}$ с двумя начальными размерами пузырьков $a_{0}=10^{-6}$ м и $10^{-3}$ м. Изучено влияние частот возмущений и температуры среды на коэффициент затухания акустической волны.

Ключевые слова: перегретая жидкость; пузыръки; фазовый переход; гармонические волны; фазовая скорость; коэффициент затухания; приращение.

\section{Литература}

1. Кутателадзе, C.С. Тепломассообмен и волны в газожидкостных системах / C.С. Кутателадзе, В.Е. Накоряков. - Новосибирск: Наука, 1984.

2. Нигматулин, Р.И. Динамика многофазных сред / Р.И. Нигматулин. - М.: Наука, 1987.

3. Шагапов, В.Ш. Реализация высоких давлений и температур в газовой фазе при истечении пузырьковой жидкости через сопло / В.Ш. Шагапов, С.А. Лепихин, М.Н. Галимзянов // Инженерно-физический журнал. - 2007. - Т. 80, № 6. - С. 134-137.

4. Галимзянов, М.Н. Истечение двухфазной смеси через сопло с учетом фазовых переходов / М.Н. Галимзянов, С.А. Лепихин // Вестник Самарского государственного университета. Естественнонаучная серия. Механика. - 2010. - № 2(76). - С. 96-104.

5. Галимзянов, М.Н. Распространение нелинейных волн в каналах переменного сечения, сопровождаемое образованием гидрата газа / М.Н. Галимзянов, С.А. Лепихин, И.А. Чиглинцев // Вестник Самарского государственного университета. Естественнонаучная серия. Механика. - 2012. - № 3/1(94). - С. 103-115.

6. Bolotnova, R.Kh. The Hydrodynamic Processes in Bubbly Liquid Flowing in Tubes and Nozzles / R.Kh. Bolotnova, M.N. Galimzianov, A.S. Topolnikov, U.O. Agisheva, V.A. Buzina // WASET. - 2012. - № 68. - P. 1992-1999.

7. Нигматулин, Р.И. Двумерные волны давления в жидкости, содержащей пузырьковые зоны / Р.И. Нигматулин, В.Ш. Шагапов, И.К. Гималтдинов, М.Н. Галимзянов // Доклады Академии наук. - 2001. - Т. 378, № 6. - С. 763-768.

8. Галимзянов, М.Н. Двумерные волны давления в жидкости, содержащей пузырьки / М.Н. Галимзянов, И.К. Гималтдинов, В.Ш. Шагапов // Известия Российской академии наук. Механика жидкости и газа. - 2002. - № 2. - С. 139-147.

9. Галимзянов, М.Н. Распространение волн сжатия в пузырьковых зонах конечных размеров / М.Н. Галимзянов // Вестник Удмуртского университета. Математика. Механика. Компьютерные науки. - 2010. - № 2. - С. 57-66.

10. Bolotnova, R.Kh. Nonlinear Effects in Bubbly Liquid with Shock Waves / R.Kh. Bolotnova, M.N. Galimzianov, A.S. Topolnikov, V.A. Buzina, U.O. Agisheva // WASET. - 2012. № 68 . - P. 2000-2007.

11. Болотнова, Р.Х. Моделирование процессов взаимодействия сильных ударных волн в газожидкостных смесях / Р.Х. Болотнова, М.Н. Галимзянов, У.О. Агишева // Известия высших учебных заведений. Поволжский регион. Физико-математические науки. 2011. - № 2. - C. 3-14.

12. Агишева, У.О. Параметрический анализ режимов ударно-волнового воздействия на газожидкостные среды / У.О. Агишева, Р.Х. Болотнова, В.А. Бузина, М.Н. Галимзянов // Известия Российской академии наук. Механика жидкости и газа. - 2013. - № 2. C. $15-28$.

13. Hawker, N.A. Interaction of a Strong Shockwave with a Gas Bubble in a Liquid Medium: a Numerical Study / N.A. Hawker, Y. Ventikos // Journal of Fluid Mechanics. - 2012. № $701 .-$ P. 59-97. 
14. Агишева, У.О. Распространение волн давления слабой интенсивности в жидкости, содержащей слой пузырьков / У.О. Агишева, М.Н. Галимзянов, Э.З. Заляева // Труды Института механики им. Р.Р. Мавлютова Уфимского научного центра РАН. - 2017. T. 12, № 2. - C. 244-249.

15. Шагапов, В.Ш. Распространение малых возмущений во вскипающей жидкости, содержащей газовые зародыши / В.Ш. Шагапов, О.А. Зайнуллина // Теплофизика высоких температур. - 2015. - Т. 53, № 1. - С. 91-97.

16. Шагапов, В.Ш. Особенности отражения и преломления акустических волн на границе раздела между газом и дисперсной системой / В.Ш. Шагапов, В.В. Сарапулова // Прикладная механика и техническая физика. - 2015. - Т. 56, № 5. - С. 119-129.

17. Шагапов, В.Ш. Особенности преломления и отражения звука на границе пузырьковой жидкости / В.Ш. Шагапов, В.В. Сарапулова // Акустический журнал. - 2015. - Т. 61, № 1. - С. $40-48$.

18. Губайдуллин, Д.А. Акустика жидкости с полидисперсными парогазовыми пузырьками / Д.А. Губайдуллин, Ю.В. Федоров // Инженерно-физический журнал. - 2017. - Т. 90, № 2. - С. 325-333.

19. Губайдуллин, Д.А. Затухание акустического сигнала, распространяющегося через два слоя пузырьковой жидкости / Д.А. Губайдуллин, А.А. Никифоров // Инженернофизический журнал. - 2018. - Т. 91, № 1. - С. 214-220.

20. Шагапов, В.Ш. Особенности отражения и прохождения акустических волн на границе «чистой» и пузырьковой жидкостей при прямом их падении / В.Ш. Шагапов, М.Н. Галимзянов, И.И. Вдовенко // Теплофизика высоких температур. - 2019. - Т. 57, № 2. C. $284-290$.

21. Шагапов, В.Ш. Особенности отражения и прохождения акустических волн на границе «чистой» и пузырьковой жидкостей при «косом» их падении / В.Ш. Шагапов, М.Н. Галимзянов, И.И. Вдовенко // Теплофизика высоких температур. - 2019. - Т. 57, № 3. C. $464-468$.

22. Шагапов, В.Ш. Особенности устойчивости и акустических свойств перегретой жидкости с газовыми зародышами при повышении давления / В.Ш. Шагапов, М.Н. Галимзянов, И.И. Вдовенко // Теплофизика высоких температур. - 2019. - Т. 57, № 5. - С. 748-754.

23. Шагапов, В.Ш. Акустика и устойчивость перегретой жидкости с газовыми зародышами / В.Ш. Шагапов, М.Н. Галимзянов, И.И. Вдовенко // Прикладная механика и техническая физика. - 2019. - Т. 60, № 3. - С. 85-95.

24. Нигматулин, Р.И. Проявление сжимаемости несущей фазы при распространении волны в пузырьковой среде / Р.И. Нигматулин, В.Ш. Шагапов, Н.К. Вахитова // Доклады АН CCCP. - 1989. - Т. 304, № 5. - С. 1077-1081.

25. Ландау, Л.Д. Гидродинамика / Л.Д. Ландау, Е.М. Лифшиц. - М.: Физматлит, 2006.

26. Варгафтик, Н.Б. Справочник по теплофизическим свойствам газов и жидкостей / Н.Б. Варгафтик. - М.: Наука, 1972.

Ульяна Олеговна Агишева, кандидат физико-математических наук, лаборатория «Механика многофазных систем», Институт механики им. Р.Р. Мавлютова УФИЦ PAН (г. Уфа, Российская Федерация), agisheva_u@mail.ru.

Марат Назипович Галимзянов, кандидат физико-математических наук, доцент, лаборатория «Механика многофазных систем», Институт механики им. Р.Р. Мавлютова УФИЦ РАН (г. Уфа, Российская Федерация), monk@anrb.ru.

Поступила в редакцию 4 апреля 2019 г. 